\title{
Gränsöverskridande meningsskapande. Om relevansen hos begrepp som text och sakprosa för förståelsen av hälsokommunikation
}

Tidsskriftet Sakprosa

Bind 10, Nummer 1

(C) 2018

10.5617/sakprosa.5725
A. Karlsson og M. Landqvist
$1 / 31$
Sakprosa.no 


\section{Sammendrag}

I artikeln problematiseras etablerade gränsdragningar och dikotomier inom text- och interaktionsforskning, med särskilt fokus på begreppet sakprosa. Kommunikationsprocesser om hjärtfel används för att visa på skärningspunkterna mellan medieringsformer, roller och kunskapsdomäner. Det empiriska materialet utgörs av konsultationssamtal mellan gravida och läkare, onlineforum på nätet och bloggar skrivna av föräldrar till barn med medfödda hjärtfel. De tre fallen jämförs med avseende på medieringsresurser, kunskapspositionering och framställningsformer. Resultaten visar att konsultationssamtalen är monologiska och textliknande medan skrift, särskilt i forumen, används på otraditionella och dialogiska sätt. I forum och bloggar bygger deltagare expertis utifrån personlig erfarenhet. I samtalen framstår läkarens framställningsformer som starkt styrande. Läkarna har dock inte alltid den största auktoriteten. Expertroller förhandlas i varje situation, och gränserna för fackkunskap är oskarp. Kunskap dock genomgående ett viktigt kapital, och olika typer av kunskap tillskrivs olika värde i de olika kontexterna. En utmaning för modern fackkommunikationsforskning är att bättre förstå dynamiken och nätverken som är involverade när saklig kunskap görs relevant $i$ verkliga livssituationer.

\section{Abstract}

In this article, established boundaries and dichotomies in text and interaction research are discussed and problematized. Examples from different communicative encounters in heart failure communication are used to illustrate the intersections of mediational resources, roles, and knowledge domains. Data comes from consultations between pregnant couples and physicians, online forums discussions and blogs written by parents to children with congenital heart failure. These three cases are compared with
A. Karlsson og M. Landqvist
$2 / 31$
Sakprosa.no 
regard to mediational resources, knowledge positionings and forms of presentation. The results show that while the consultations are monological and 'text like', writing is used in untraditional and dialogical ways in forums and blogs, in which expertise is based on personal experience. In the consultations, the doctor's presentation appears to be decisive. But doctors do not always have the greatest authority. Expert roles are negotiated in each situation, and the limits of specialist knowledge are blurred. Knowledge is an important capital, and different types of knowledge are given different values in the different contexts. A challenge for modern professional communication research is to grasp the dynamics and networks involved when making specialist knowledge relevant to real life situations.

\section{Om forfatterne:}

Anna-Malin Karlsson er professor i svensk ved Institutionen för nordiska språk ved Uppsala Universitet.

Mats Landqvist er professor ved Institutionen för kultur och lärande ved Södertörns högskola. 


\section{Gränsöverskridande meningsskapande. Om relevansen hos begrepp som text och sakprosa för förståelsen av} hälsokommunikation

En vanlig uppfattning inom språk- och textvetenskapen, inte minst inom literacyforskningen, är att vi lever i en textualiserad värld. Detta kan förstås snävt, som att vi gör alltmer med hjälp av skrivna texter, eller brett, som att vi agerar och handlar genom formuleringar och kommunikation. Oavsett vilket kan man utan att överdriva säga att vi i hög utsträckning hanterar verkligheten genom språkliga yttranden. En benämning för en del av - men inte alla - de formuleringar som handlar om verkligheten är sakprosa. Verklighetsförankringen är i själva verket central i de definitionsförslag som publicerades i samband med att tidskriften Sakprosa etablerades. I boken Hva er sakprosa (2008, s. 34) föreslår Tønnesson att sakprosa definieras som ”tekster som adressaten har grunn til å oppfatte som direkte ytringer om virkeligheten". ${ }^{1}$

Forskning som följer människor i deras textburna, sakinriktade meningsskapande, i och mellan olika kommunikationssituationer, når dock ganska snart insikten att gränserna mellan yttranden av olika slag är både mer diffusa och mer komplexa än i den textvetenskapliga teorin. Vår teoretiska kunskap om distinkta genrer, texttyper och kunskapskulturer bygger nämligen ofta på renodlingar, och utgår vanligen från en specifik institutionell

\footnotetext{
${ }^{1}$ Berge \& Tønnesson (2009) resonerar vidare på detta spår och nyanserar tanken att relationen mellan text och verklighet skulle kunna vara "direkt" i absolut och universell mening. Vår tolkning är att verklighetsrelationen ska förstås i jämförelse med fiktionslitteraturens tydligt indirekta verklighetsbeskrivning, och att distinktionen mellan sakprosa och fiktionslitteraturen handlar om den tolkningsram som läsaren erbjuds och accepterar.
}
A. Karlsson og M. Landqvist
$4 / 31$
Sakprosa.no 
domän, texttyp eller avsändarroll - inte sällan en professionell sådan. Risken med detta är att vår förståelse för hur kunskap medieras i dagens samhälle blir begränsad.

Syftet med denna artikel är att problematisera etablerade gränsdragningar och dikotomier inom text- och interaktionsforskning, med särskilt fokus på begreppet sakprosa. Detta gör vi med utgångspunkt i studier av kommunikationsprocesser om hjärtfel. Nedslag i dessa processer får exemplifiera hur mening skapas i skärningspunkterna mellan medieringsformer, genrer och verksamhetstyper, kommunikativa roller och domäner.

\section{Text och sakprosa}

Inom humanistisk forskning förekommer en rad begrepp och kategorier som bygger på dikotomier och prototyptänkande. Textforskningen är inget undantag. Själva textbegreppet är ofta beroende av motsatser och negativa motpoler för att definieras. Ett sätt att förstå text som språkvetenskapligt studieobjekt är att det är språk i bruk, och alltså inte det som traditionellt studeras som språksystemet. Textforskning blir då den språkforskning som inte är grammatikforskning. En vanligare uppdelning är den mellan texter och samtal, där textforskning blir forskningen om det språkbruk som inte analyseras som samtal (och tvärt om). ${ }^{2}$

Ledin (1999) definierar text utifrån finalitet, dvs. att det ska vara ett avslutat yttrande som söker en reaktion hos någon annan. Denna finalitet är dock konventionellt bestämd, dvs. det avgörs inom ramen för en kultur vilka

${ }^{2}$ Dessa och andra perspektiv på textforskning som fält diskuteras i Svensson \& Karlsson (2012) samt Karlsson \& Makkonen-Craig (2014). 
yttranden som får textstatus. En liknande kulturberoende textsyn finns hos Berge (1993), som talar om texter som yttranden som tillskrivs kulturellt värde inom en kultur. Texter skiljs därmed dels från yttranden utan kulturellt värde, dels från yttranden som inte är tillräckligt självständiga för att fungera som utgångspunkt för respons. Dialog sker med detta synsätt framförallt mellan texter. Samtidigt är det uppenbart att texter också är dialogiska i sig: de rymmer, inom ramen för det avslutade yttrandet, också spår av andra yttranden, direkt eller indirekt (jfr t.ex. Tønnesson, 2001.) Traditionellt har vi hjälp av texters materialitet när vi vill avgränsa dem: en prototypisk text är också en materiellt avgränsad enhet. Digitala medier och annan kommunikationsteknologi utmanar dock denna konvention - också kanske även vårt behov att alls avgränsa texter från varandra, särskilt om textanvändarnas textbegrepp förändras.

Textforskare kan vidare intressera sig för skönlitteratur eller sakprosa, där det senare utmärks av att vara motsatsen till det förra, dvs. behandla en icke-fiktiv verklighet. Sakprosa som studieobjekt har ofta konstaterats vara något av en nordisk specialitet: medan internationell (särskilt engelskspråkig) forskning intresserar sig för facktexter eller "language for specific purposes", med tanken att dessa ska utgöra mål för utbildning, menar nordiska sakprosaforskare att sakprosa är intressant i sin egen rätt. Berge (2001) beskriver studieobjektet sakprosa på följande sätt:

Med ordet "sakprosa" følger det [...] en slags normativ språkfilosofisk ideologi om hvordan tekster kan reindyrkes til visse oppgaver eller funksjoner.

Sakprosatekster er da tekster der en "sak", et "emne" eller en "gjenstand" så og si vises fram, mest hensiktsmessig på en måte som gjør at språket overses eller ikke insisterer på å bli lagt merke til. Et kvalitetsstempel på god sakprosa er derfor at den er "klar" og "nøytral". I den populære bevissthet står "formen" ikke i veien for det såkalte "innholdet" i en sakprosatekst. 
Berge noterar dock att detta kan tolkas på olika sätt, beroende på vilken vetenskaplig tradition som studiet av sakprosa inordnas i. En skiljelinje går mellan studiet av de mycket lästa brukstexterna och studiet av sakprosa som litteratur, med fokus på namngivna författare och texter med verkshöjd. (Se Tønnesson 2008 för ett utvecklat resonemang om litterär respektive funktionell sakprosa.) Denna uppdelning resulterar i olika motiv för studiet av sakprosa. Att förstå sakprosa som vardagens bruksprosa, och studera de texter många använder mer eller mindre oreflekterat, blir ett sätt att förstå grundvillkoren för (skrift)språklig kommunikation, och språkets roll i samhället. Studiet av sakprosa som litteratur breddar snarare förståelsen av vad ett litterärt verk kan vara, och bidrar till att höja statusen på sakliga texter och faktabaserat författarskap och gör sakprosaforskningen i högre grad mångvetenskapligt humanistisk. I den senare förståelsen ingår med självklarhet att sakprosa är skriven, medan det förra perspektivet i högre utsträckning kan öppna för andra medieringar, och för inkludering av sakinriktade (professionella) samtal.3

I en av de teoretiskt sammanfattande texterna från det svenska sakprosaprojektet resonerar Englund, Ledin och Svensson (2003) om vad sakprosa är och kan vara. De kan konstatera att projektet har koncentrerat sig på tryckta, mycket lästa texter som behandlar verkligheten, men menar också att sakprosa måste förstås utifrån sitt historiska sammanhang, som en "social realitet”. Sedan sakprosaprojektet avslutades har villkoren för spridning av

\footnotetext{
3 Den senast tillsatta sakprosaprofessorn i Norge har en forskningsinriktning mot professionella samtal, och förestår det nyöppnade Senter for faglig kommunikasjon. Gränsen mellan sakprosa (som litteratur) och professionell kommunikation (i tal och skrift) som forskningsfält kan därmed sägas ha blivit mindre skarp. Tønnesson har också, iden andra utgåvan av Hva er sakprosa (2012, s. 34), strukit ordet "skriftlig" i den delen av definitionen som gäller medieringsformer: "Sakprosateksten kommuniserer gjennom [skriftlig] verbalspråk, men dette skjer ofte i samspill med andre tegnsystemer.”
} 
texter förändrats radikalt. Att idag avgränsa ett forskningsfält med att texterna ska vara tryckta vore endast motiverat om forskningen ska skriva just trycksakshistoria - inte om det ska handla om det som många läser och använder. Den tekniska förändringen kan också motivera ett ifrågasättande av andra kriterier: som att sakliga texter med stor betydelse för information och kunskapsspridning nödvändigtvis är skrivna (och inte talade eller multimodala), liksom att de enbart behandlar verkligheten.

Vi menar att begreppet sakprosa bör prövas med utgångspunkt i autentiska kommunikationsprocesser (jfr Karlsson \& Strand, 2012), med syftet att undersöka hur väl den "sociala realiteten” förmås ringas in. Det fall vi vill använda för detta är på många sätt lämpligt: det handlar om fackkunskap som ska förmedlas till lekmän, det involverar institutioner och professioner fenomen som ofta aktualiseras när sakprosa som verksamhetsområde ska avgränsas - och det tillhandahåller empirisk grund för en diskussion om tal, skrift och visuella representationer som medierande resurser.

\section{Utgångspunkter, exempel och disposition}

Hälsolitteracitet och kunskapsbyggande i informationssamhället är ett nyligen avslutat projekt som undersökt språklig medierat meningsskapande och kunskapsbyggande i samband med en diagnos om hjärtfel hos ett väntat barn. 4 Projektet designades för att fånga kommunikations- och medieringsprocesser, och för att nå en förståelse av hur kunskap byggs i kommunikativa kedjor och nätverk av texter och kontexter. Det innebär att projektets material varit mångfacetterat. Det har bestått av inspelade konsultationssamtal och återbesök hos läkare, de skisser som ritas under läkarsamtalen, intervjuer med gravida och deras partner samt med föräldrar

4 Projektet finansierades av det svenska Vetenskapsrådet 2015-2017.
A. Karlsson og M. Landqvist
$8 / 31$
Sakprosa.no 
till barn med medfödda hjärtfel, faktasidor på nätet som de personer vi intervjuat säger att de läst, bloggar skrivna av föräldrar, intervjuer med bloggare, inlägg på Instagram, böcker och broschyrer m.m. I stället för att beskriva och karakterisera en särskild sorts texter eller samtal har vi alltså arbetat för att analysera relationen mellan olika texter, samtal och situationer. Utgångspunkten har varit individens vägar genom informationslandskapet. De vägar som fångats i projektet menar vi är representativa för kommunikativa utmaningar som människor dagligen konfronteras med oavsett om det gäller akut sjukdom eller andra livsomvälvande händelser.

Ett övergripande dialogiskt perspektiv (Linell 2009) kompletteras med en socialsemiotisk ram för analysen av diskurs. I analysen av bloggar (Bellander, 2016) har genre (Martin \& Rose, 2012) använts för att analysera språk som social handling. I analysen av konsultationssamtalen (Landqvist \& Karlsson, u.u..) har vi använt den kunskapssociologiska modellen Legitimation Code Theory (Maton m.fl. 2015), som förstår diskursivt kunskapsbyggande som en rörelse mellan olika språkligt realiserade kunskapskulturella fält, beskrivna i termer av koder. Kontext och diskurs har analyserats som ömsesidigt beroende av varandra, och den centrala undersökningsenheten har varit situationen.

Tre fall fungerar som utgångspunkter för resonemangen i denna artikel: för det första de konsultationssamtal där den gravida med eventuell partner möter en specialist och får en diagnos för fostret, för det andra de onlineforum på nätet där privatpersoner kan diskutera hälso- och sjukdomsrelaterade frågor, och där erfarenheter av tidigt diagnostiserade hjärtfel utbyts, och för det tredje bloggar som drivs av föräldrar till så kallade "hjärtebarn" 5, dvs.

5 “Hjärtebarn” är den benämning som föräldrarna själva använder om barn som fötts med hjärtfel. Deras patientorganisation heter "Hjärtebarnsförbundet”.
A. Karlsson og M. Landqvist
$9 / 31$
Sakprosa.no 
barn som lever med medfödda hjärtfel. Dessa fall behandlas i tur och ordning med fokus på följande teman:

- De medieringsresurser som erbjuds och används (tal, skrift, bild, dialog, monolog).

- De kunskapspositioneringar som intas, dvs. hur deltagarna förhåller sig dels till kunskap som sådan, dels till olika kunskapsägande aktörer som är relevanta i sammanhanget.

- De framställningsformer, dvs. språkliga sätt att koda kunskap, och därigenom relatera den till olika kunskapskulturer, som förekommer och hur dessa förhåller sig till varandra.

Avslutningsvis förs ett samlat resonemang om vad som framkommit om de tre kontexterna, och utifrån detta återkommer vi till frågan om hur gängse gränser och prototypiska kategorier utmanas genom en praktik-, och processorienterad studie av kommunikation.

\section{Konsultationssamtalen: evidens och relevans}

När en missbildning av hjärtat misstänks efter rutinultraljudet under en graviditet remitteras den gravida kvinnan till en specialist, som gör en mer omfattande undersökning. Direkt efter denna undersökning, i samma rum, tar ett konsultationssamtal vid. Här förmedlar läkaren undersökningens resultat, förklarar möjliga, kirurgiska, behandlingsmetoder samt informerar om den närmaste tidens olika praktiska steg. I det tiotal konsultationssamtal vi spelat in deltar även den gravidas partner och i några fall även en sjuksköterska.

Den huvudsakliga medieringsresursen i samtalen är den muntliga dialogen, där deltagarna orienterar sig mot varandra och den konsulterade läkaren söker kontakt med och strävar efter förståelse hos den andra parten. En
A. Karlsson og M. Landqvist
$10 / 31$
Sakprosa.no 
dialogisk inställning är också en bärande del i den vårdande verksamhet som samtalet är en del av. Emellertid visar våra analyser att det nästan bara är läkaren som talar (Melander Marttala \& Mattson, 2017, Landqvist \& Karlsson, u.u..). Samtalen innehåller alltså få sekvenser med så tät verbal turtagning att en interaktionell analys av CA-typ skulle vara motiverad. Istället har det varit motiverat att se läkarens relativt monologiska framställningssätt som en text, och studera hur hen i dessa yttranden hanterar kunskap, förhåller sig till den och därigenom formar förutsättningarna för parets kunskapsbyggande (Landqvist \& Karlsson, u.u..). Att läkarens framställning följer ett fast mönster, och varierar förhållandevis lite mellan samtalen, bidrar också till att vi vill tillskriva den textstatus.

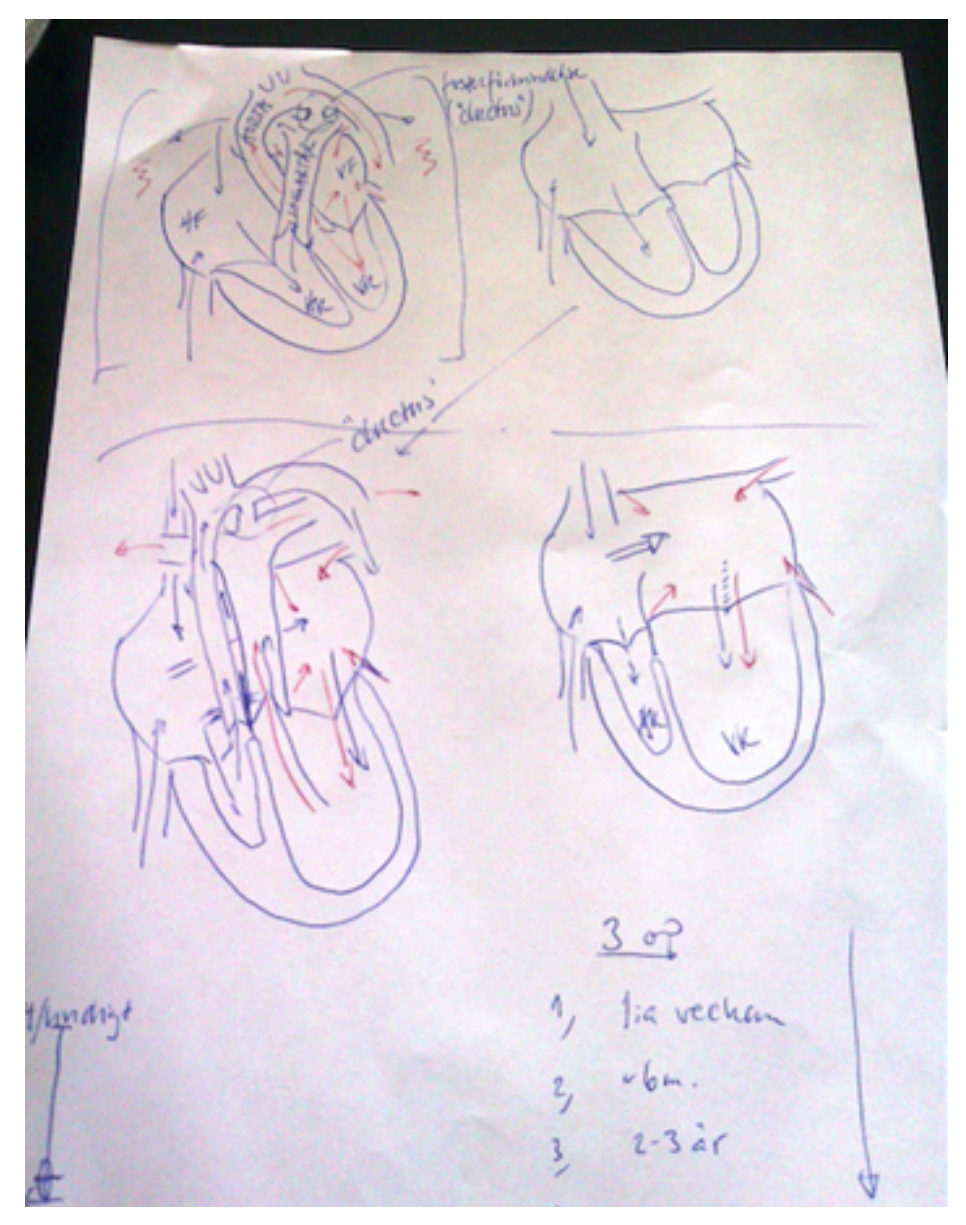

Figur 1. Exempel på skiss som ritas under konsultationssamtalen 
En viktig medieringsresurs i konsultationssamtalet är de bilder, modeller och skisser som ackompanjerar informationsgivandet. Läkarna ritar skisser av hjärtan, alternativt använder färdiga skisser som fylls i med relevant information, under den inledande delen av samtalet. Skissen visar dels ett normalt, friskt hjärta, dels det dysfunktionella hjärta som läkaren sett på ultraljudet. (Se figur 1.) Ritandet och talandet sker simultant. Det gör att de som lyssnar kan titta på den framväxande bilden samtidigt som de får höra vad som är fel med fostrets hjärta. På så sätt understryks den tematiska sekventialiteten i konsultationen, dvs. den pedagogiska ordning som informationen presenteras i, och paret kan använda såväl visuella som audiella resurser för att bygga ny kunskap. Skissandet bidrar med ytterligare affordanser, dvs. möjligheter till kommunikation och meningsskapande, för patienternas lärande under samtalet. Där talet är flyktigt och försvinner i takt med att ljudvågorna klingar ut, är istället bilden beständig. Den kan paret ta med hem och använda senare, i samtal med anhöriga eller för ytterligare informationssökningar på Internet.

Talet och bilden ger olika utrymme för detaljdjup, perspektiv och schematisering. Bilden skapar överblick men ger även fokus på särskilt relevanta detaljer och delar av hjärtat. Där går också att visa hur t.ex. en operation går till. Talet har större möjligheter att utveckla resonemangen och referera till olika aspekter av problemet. I exempel (1), även analyserat i Landqvist \& Karlsson (u.u.), utvecklar läkaren vad de anatomiska fel som skissen visar innebär. (L står för läkare.) 
Exempel 1. Konsultationssamtal

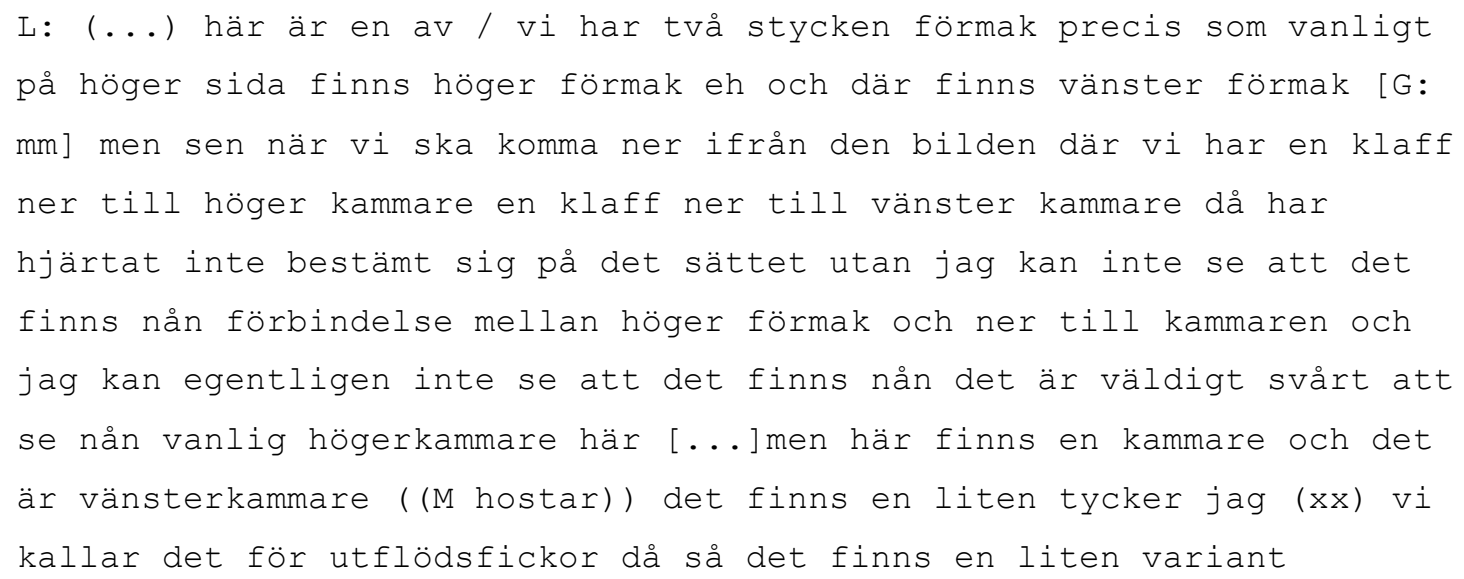

Samtalet behandlar i samtliga fall diagnosen, eventuell kirurgi, hjärtfelets konsekvenser för framtida liv, den fortsatta graviditeten och läkarkontaktsamt eventuella framtida graviditeter. Under de mest medicinskt fackmässiga partierna pendlar läkarnas framställning mellan två nivåer, en där de håller sig till den specifika kontexten för det aktuella fallet, och en mer generell och evidensbaserad nivå, där de kan vila på och hänvisa till expertkollektivets vetenskapligt baserade kunskap. Att dessa två nivåer existerar parallellt, även inom ramen för ett samtal kan tolkas som att en ambivalens råder om vilken bas som användbar kunskap ska ha. Evidensbaserad medicinforskning, som alltså bygger på statistiskt säkerställda resultat från vetenskapliga studier av stora datamängder, har framhållits som ett ideal under mer än tjugo års tid, men har visat sig ha begränsat värde i medicinsk praktik. ${ }^{6}$ Den generella

\footnotetext{
${ }^{6}$ Invändningarna är i huvudsak följande (efter Greenhalgh m.fl. 2014): Den stora mängden statistisk och evidensbaserad kunskap inom ett specifikt fält tenderar snart att peka mot motstridiga slutsatser och fungerar därför mindre bra som medicinsk vägledning. Hänvisning enbart till statistiska resultat riskerar vidare att skapa en vårdsituation som inte är patientcentrerad. Statistisk evidens räcker heller inte för att kartlägga komplexa tillstånd med olika bakomliggande orsaker.
} 
kunskapen måste alltså vägas i relation till det aktuella fallet och den kollegiala erfarenheten av liknande fall, vilket speglas i läkarens framställning.

I exempel (2), också från Landqvist \& Karlsson (u.u.), hänvisar läkaren till vad som enligt den samlade erfarenheten “inte är ovanligt”. (P står för partner.)

Exempel 2. Konsultationssamtal

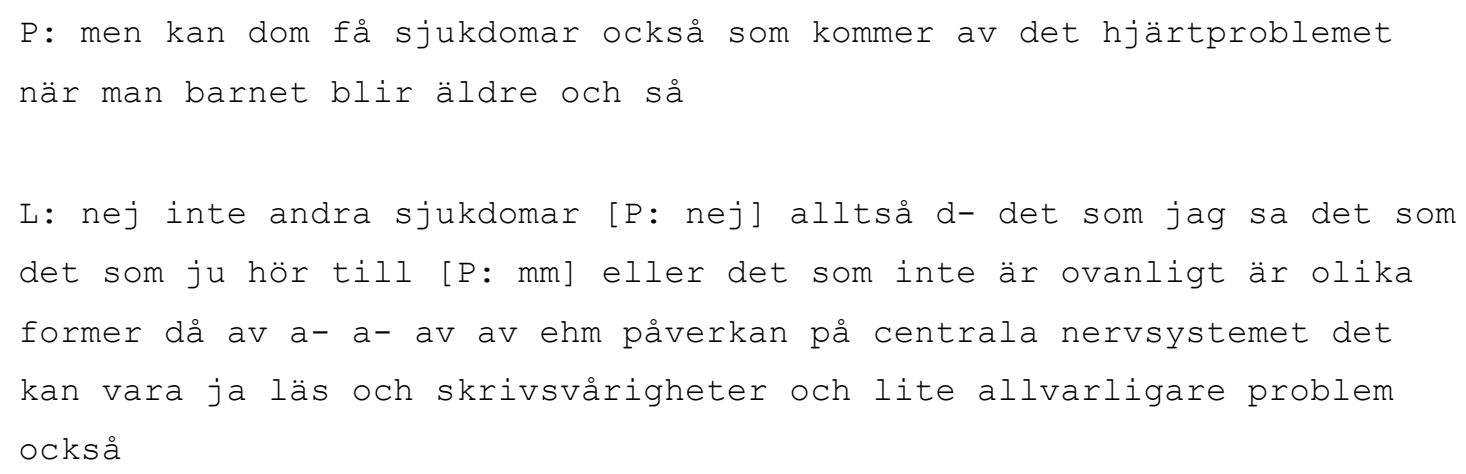

Växling av kontextnivå sker även när framställningen gäller barnets framtid.

Då finns det dock sällan evidensbaserad kunskap att tillgå, utan läkaren talar i mer allmänt generella termer, med hjälp av metaforer och bilder av olika vardagssituationer. Här reagerar paren oftast med större engagemang - det handlar ju konkret om deras framtida tillvaro. Än mer tenderar de att delta när det handlar om sådant som fortsatt graviditet och förlossning, ämnen som ligger i den omedelbara framtiden och där de behöver göra egna avgöranden. Man kan säga att det kunskapsrelaterade ansvaret fördelas mellan den professionella representanten, läkaren, som ger förutsättningar, förhållningsorder, och skapar struktur, och paret som måste ta ansvar för att förbereda sig för det som ska ske (t.ex. föda barnet på en viss klinik eller acceptera att den nyfödda ska opereras). Kunskapspositionerna är alltså olika och växlar med upplevd grad av angelägenhet, expertdjup och ansvar.

I ett konsultationssamtal aktualiseras alltså flera olika kunskapsframställningar: en som handlar om medicinsk, generaliserad och 
evidensbaserad kunskap om hjärtfel och behandling, en som rör mer specifikt medicinskt "hantverk", s.k. beprövad erfarenhet, (se t.ex. Sacket m.fl. 1996 om indelning av medicinsk kunskap) som hur man förbereder för och genomför undersökningar, förlossning och behandlingar, samt en som står för en livsvärldsförankrad sjukdomsbeskrivning som riktar sig mot framtiden, ibland framställd med målande exempel. Diagnoser och anatomiska beskrivningar får en mer teoretisk, faktamässig form än de aktuella behandlingarna, som ofta framställs som en konkret läkarpraktik. Ytterligare en typ av kunskapsframställning är den framtidsbild som utmålas för det ännu ofödda barnet, som ju är preliminär. Paren måste, för att förstå, kunna hantera dessa kontexter och de skillnader som de innebär. Läkarna använder dessutom olika typer av semantik. Olika semantiska koder representerar olika perspektiv på kunskap, och dessa kan tillsammans hjälpa patienten att förstå och greppa situationen. Så kan en vardaglig beskrivning vara lätt för paren att identifiera sig med, t.ex. "när man börjar på förskola så man har inte samma ork du kan aldrig liksom öva upp din kondition utan du har en tänk dig en påse med ork och när den orken är slut då måste du sova”. En mer fackspråklig och tätare semantik blir istället mer neutral, t.ex.: "ett barn med funktionshinder som innebär att det har nedsatt funktionsförmåga och nedsatt uthållighet”.

Sammanfattningsvis kan vi konstatera att konsultationssamtalen är sammansatta vad gäller mediering, kunskapspositionering och språklig framställning av kunskap, samtidigt som de i relativt liten grad är interaktiva. Gränsöverskridandet handlar dels om en växling mellan olika kunskapsobjekt (hjärtfelet, behandlingar, graviditet, förlossning) och sätt som dessa framställs på (specifikt, generellt och bildligt), dels om växlingar mellan olika positioneringar. Läkaren pendlar mellan rollen som diagnostiker, den som behandlande läkare och den som pedagog. Växlingen mellan dessa olika positioner kan i sig säga oss något om professionell kommunikation (se Sarangi, 2000), men hänger framförallt ihop med målet att under samtalet ge så komplett information som möjligt. Detta gör det nödvändigt att gå utanför 
och växla mellan kunskapsdomäner, eftersom den kompletta och relevanta kunskap som paret behöver varken ryms inom den evidensbaserade medicinska vetenskapen, den hantverksmässiga kirurgiska kunskapen eller den anekdotiska kunskapen om framtida liv, utan bara kan skapas i kopplingarna mellan dessa.

\section{Forum: expertis och empati}

En del av de gravida som får besked om medfött hjärtfel hos fostret söker sig till diskussionsforum på Internet. Dessa är ofta underavdelningar till större, mer allmänna forum, som exempelvis det svenska Familjeliv. I projektet har vi undersökt ett begränsat antal trådar i ett forum för medfödda missbildningar.

I forumen kan en nybörjare ställa sina frågor och ge uttryck för sin oro samtidigt som andra deltagare med större erfarenhet av den medicinska situationen kan bidra med mer omfattande och ingående resonemang. De främsta medierande resurserna är dialog och skrift, två redskap som när det gäller affordanser pekar åt något olika håll. Om vi börjar med dialogen kan vi konstatera att nya deltagare positionerar sig som informationssökande, vilket inte är särskilt anmärkningsvärt. Mer intressant är de dialogiska syften som utvecklas. Vill man studera forumen som ett sammanhang för kunskapsbyggande räcker det därför inte att som forskare enbart fokusera på de enskilda inläggen.

Skriftligt medierad interaktion har tidigare studerats i exempelvis chattkonversationer, ofta med fokus på pausering och upprätthållande av en pågående dialog (se t. ex. Giles m.fl., 2015). Utgångspunkten är då samtalet, och intresset ligger på hur det påverkas av att det sker i skrift. Vänder man på perspektivet, och intresserar sig för villkoren för kunskapsbyggande i språklig kommunikation, blir det dialogiska snarare något att utforska närmare. Exempelvis blir det då intressant att undersöka om inlägg med en viss typ av
A. Karlsson og M. Landqvist
$16 / 31$
Sakprosa.no 
innehåll eller syfte får en viss typ respons, som i sin tur kan påverka dialogens vidare utveckling. Det är alltså inte så enkelt som att en fråga får ett svar, en inbjudan ett accepterande, en hälsning en hälsning etc. Alla inlägg i ett forum får inte svar, och några inlägg attraherar kanske bara ett eller ett par responser. De foruminlägg som inleder en längre kedjor av kommunikation verkar kännetecknas av att de tillhandahåller ny information - ofta specialiserad så att vissa, men inte vem som helst, känner sig manade att svara. Genom detta sätt att skriva fram intresseväckande aspekter av den kunskap som förhandlas bidrar deltagarna till att skapa grupperingar, eller gemenskaper, som kan samlas kring ett tema och utveckla nya insikter kring det (Landqvist 2016). I dessa specialiserade dialoger ges utrymme för s.k. lekmannaexpertis, dvs. kunskap utvecklas och förmedlas deltagarna emellan.

Skriften som resurs skapar stabilitet och avgränsning. Inläggen står kvar och deltagare kan söka sig dit flera gånger. Inlägg kan läsas av många, vid olika tillfällen och flera gånger. Skriften bidrar på så sätt till att binda samman deltagare. De grupper av skribenter som forumet på så sätt skapar förhåller sig vanligen på ett explicit sympatiskt sätt mot varandra, för att inte säga inkännande. Bland forumets aktiva deltagare verkar en kultur utvecklas där empati, identifikation och beredvillighet att dela med sig av erfarenheter är centrala komponenter. En annan typ av positionering sker gentemot de kunskapande aktörer som inte deltar i forumet men som är andligen närvarande i referenser och genom återberättande av deltagarnas erfarenheter. Ett exempel från våra analyser är när dessa aktörer är vårdpersonal som deltagarna mött i olika sammanhang (Landqvist, inskick.). Därtill finns gott om referenser till möten, skrifter, bilder, webbplatser och liknande där den professionella vården informerar om det aktuella hälsotillståndet. Positioneringen mot vården är emellertid inte entydig. Den kan vara alltifrån vördnadsfull till skeptisk och starkt kritisk. Deltagarna uttrycker ofta oro som en del av de upplevelser som de delar med sig av i forumen. Sådan oro sägs ofta ha uppstått i samband med att vården brustit i 
omsorg eller information. Uttrycken för oro kan skapa trådar av dialog där texten på olika sätt förhåller sig kritisk till hur kunskap har förmedlats av vården, och i samband med det skapas ibland vad man kan kalla en rättighetsdiskurs. Det innebär att deltagarnas kunskapsanspråk ökar och texterna blir mer kunskapstäta, med drag som längre men mer koncisa meningar, fler och längre sambandsmarkörer, fler facktermer osv. En lekmannaexpertis framträder hos deltagarna. Exempel (3), från Familjeliv.se, visar ett sådant mönster.

Exempel 3. Foruminlägg

Det vi också gör är att även om pk:t ${ }^{7}$ pendlar lite och kanske är lite för högt så skall man undvika att sänka dosen om det inte är absolut nödvändigt för ju mer man ändrar på dosen desto mer pendlar värdet. Det kan handla om att man ätit dåligt ett par dagar, då stiger pk:t, (blir mer koncentrerat) om man då sänker dosen, samtidigt som barnet kanske börjar äta mer, så är risken att man hamnar för lågt istället, dvs ofta är det tillfälliga saker som gör att värdet går upp och ner och därför skall man undvika ändringar av dosen. /.../

I detta relativt långa inlägg finns gott om kausala sambandsled, vilket kan visa hur deltagarens erfarenhet ger utrymme för en perspektivrik framställning. Kunskapsanspråken hos dessa lekmannaexperter ökar ju längre in i diskussionstråden man kommer. Detta inlägg är ungefär i mitten av en tråd med 20 inlägg. Kunskapen framställs som principiell även om singular bestämd form överväger (barnet, värdet, dosen), dvs. absolut form används för att referera till generella förlopp. Just så tenderar även läkarna att uttrycka sig i konsultationssamtalen, som i exempel (4) när läkaren beskriver en viss typ av operation (lungan, barnet, hålvenen).

7 Pk står för prototrombinkomplex, och är ett mått på blodets ”tjocklek”, eller egentligen koaguleringsförmåga. 
Exempel 4. Konsultationssamtal

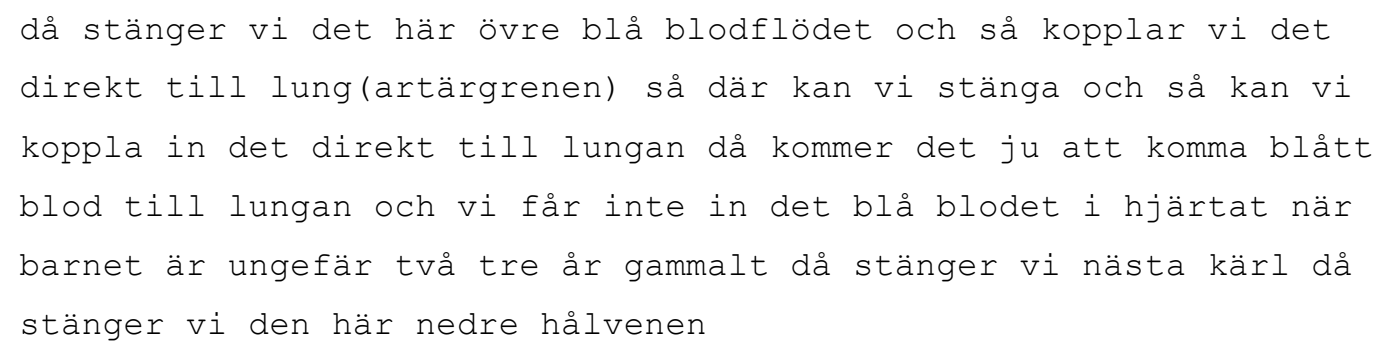

Lekmannaexperternas professionsliknande framställningssätt skapar en slags auktoritet, som verkar fungera som en resurs för den ovana, osäkra nykomlingen. Forumdeltagandet kan därmed utgöra en verksamhet med förstärkande, kanske emancipatoriska funktioner, där texter ger uttryck för en allt djupare intention och större komplexitet ju längre tid skribenterna deltagit. Potentiellt kan även forumen utgöra en arena för mobilisering av socialt motstånd, med utgångspunkt i en gemensam social positionering, både inom gruppen och gentemot andra. Ett forum bygger således på två delvis motsägelsefulla ideal: för det första utvecklingen av en dialogisk, gemenskapande kultur och för det andra en epistemologiskt auktoritativ framställning. Dessa två ideal utmanar deltagarna att framställa kunskap och göra den relevant - eller åtminstone reflektera över den. Deltagarna hanterar detta genom att omväxlande återge de professionella medicinska experternas kunskap och ge uttryck för sin egen. Vi ser också hur de gärna speglar experternas diskursiva drag, även om de förhåller sig kritiskt till dem, med en semantiskt tät struktur, och med en strävan efter att begreppsliggöra kunskapen på ett så kontextoberoende sätt som möjligt (se exempel 3). På så sätt skapas kopplingar mellan forumet och de kunskapskulturer som finns i den professionella vården och medicinvetenskapen. Samtidigt präglas inläggen, genom sin dialogiska orientering, av den kunskapskultur som man är på väg att tillsammans skapa. Här förhåller man sig till konkreta och specifika kontexter, egna reflektioner, stärkande budskap, och intar en mer interpersonell hållning.
A. Karlsson og M. Landqvist
19 / 31
Sakprosa.no 
Sammanfattningsvis kan man säga att en deltagare som vill få ut det allra mesta ur ett forum behöver balansera olika diskurser. Kännetecknande drag i forumtexter är diversitet och intertextualitet. Detta blir synligt på olika nivåer, från balansen mellan monologiska redogörelser och dialogisk interpersonell koppling till ett tydligt relaterande till olika kunskapskulturer genom specifika diskursiva drag. Som forskare når man endast begränsade analytiska mål med att försöka anpassa forumtexter och forumskrivande till analytiska mallar som skapats enbart för skrift eller muntliga samtal. Just kombinationen mellan skriftens beständighet och dialogens sociala mekanismer skapar det som utmärker forumen som epistemisk arena.

\section{Hjärtebarnsbloggar: personliga berättelser och fakta}

En del av dem som blir föräldrar till barn med medfödda hjärtfel bloggar om sin situation. En blogg är ett format på webben som fungerar som en personlig yta för kronologiskt ordnade inlägg. Huvuddelen av innehållet i de bloggar vi studerat rör livet med det hjärtsjuka barnet: operationer, läkarbesök, vardag och engagemang i patientföreningar och insamlingar. I projektet har vi samlat in ett dussin bloggar och intervjuat hälften av blogginnehavarna.

Genom bloggandet tar "hjärtebarnsföräldern" egen kontroll över de medierande resurserna: hen bestämmer själv vad hen ska skriva och vem hen ska vända sig till. Till skillnad från i forumen är framställningsformen monologisk, men till skillnad från i konsultationssamtalen är det föräldern som har ordet i monologen. Bilder är vanligt förekommande, såväl foton från vardagen som medicinska illustrationer av hjärtat. Det flesta bloggar har kommentarsfält, med få men vanligen stöttande kommentarer - både från personer som förefaller känna bloggaren och okända personer i liknande situation som tackar för en möjlighet att känna igen sig. Väldigt lite av interaktion skribenter emellan, av den typ som förekommer i forumen, kan
A. Karlsson og M. Landqvist
$20 / 31$
Sakprosa.no 
ses i kommentarsfälten. Istället är varje kommentar riktad till bloggaren och det aktuella inlägget.

Analyser i termer av genrer (Martin \& Rose, 2012) har visat att bloggen inramas av en personlig berättelse om det egna barnet. Andra genrer inordnas i och motiveras av denna makroberättelse, som är den som ger bloggaren den position som blir utgångspunkt för kommunikationen: den egna erfarenheten av att ha ett hjärtsjukt barn (Bellander 2016). I personliga återberättelser av händelser i vardagen framställer bloggaren sig själv som förälder, men även barnet, partnern och vårdpersonalen framställs - som aktiva eller passiva, som hjälpande eller hindrande. I exempel (5) berättar bloggaren Ulrika om kvällen före en av sonens operationer. Samtidigt som kvällens händelser återberättas ges också uttryck för känslor (hoppfullhet) och värderingar (av personalen).

Exempel 5. Blogg

Nu har vi varit incheckade på hotellet i några timmar, ganska fint hotell. Fått i oss lite mat och slappnat av. Hade en väldigt övertrött och mammig Theodor som tillslut somnade gott. Febern har under kvällen gått ner och låg nu vid senaste tempningen på 37,4 c, så bara till att hålla tummarna att den bara var tillfällig och att de inte visar någon infektion. Han har idag haft lite ökade kräkningar men inte allt för mycket.

Nu är det dags för några timmars sömn för att orka med morgondagens samtal och kontroller. Tur är att de verkligen är underbar personal på avdelningen, som Theodor givetvis redan hunnit charma till max.

Inom ramen för den kronologiska representation som makroberättelsen utgör infogar bloggarna även förklaringar, rapporter och ställningstaganden. Förklaringar och rapporter handlar nästan uteslutande om hjärtfelet: vad det består i och hur det kan åtgärdas, medan ställningstaganden oftast handlar om argumentation för att mer pengar behövs till forskningen om medfödda hjärtfel. En typisk förklaring, där hjärtfelet framställs, illustreras av en bild 
hämtad från en faktasida på Internet, vanligen 1177 Vårdguiden. Ofta finns två bilder: en som visar ett normalt hjärta och en som visar det aktuella hjärtfelet. Viktiga delar av hjärtat pekas ut och benämns och hjärtfelet framställs som en följd av olika orsaker, som att en kammare är för liten eller saknas, att skiljeväggen mellan kamrarna saknas eller att de stora kärlen, lungvenen och aorta, har bytt plats. Den skrivna texten ligger ofta nära texten från den aktuella faktasidan, och beskriver samma sak som bilden. Dock har vi flera exempel på hur bloggaren väver in uppgifter om vad detta innebär för just deras barn (Bellander, Karlsson \& Nikolaidou 2018). I exempel (6), från Bellander (2016), redogör bloggaren Christer för hur fosterförbindelsen, ductus, fungerar. Förklaringen (fetmarkerad av oss) är invävd i en berättelse om hur den ofödda sonen har det, och inre monolog där Christer ställer en fråga som han sedan besvarar.

Exempel 6. Blogg

Känslan när läkarna berättade det för oss måste kunna beskrivas liknande något slags negerad lottovinstkänsla. Kan man överhuvudtaget överleva utanför mammans kropp med dessa fel? Det var det första jag tänkte när vi fick höra diagnosen. Hur mår han inuti magen? Det var den andra tanken som for genom huvudet. Just nu mår Ludvig alldeles förträffligt. Han sparkar skiten ur Helene varje kväll. Det är fascinerande att se hur magen buktar och kränger när han rör på sig därinne. Eftersom Helene och Ludvig delar blodomlopp via navelsträngen i fosterlivet så påverkas han inte alls av hjärtfelet därinne. Skönt! Under fosterstadiumet har alla barn en förbindelse mellan aorta och lungpulsådern kallad duktus. Det är en ven, eller åder, vars funktion är att låta blodet transporteras mellan dessa två kärl utan att passera hjärtat. Normalt så stängs duktus inom något eller några dygn efter födseln eftersom den hos normala barn inte längre behövs då. I Ludvigs fall är det dock viktigt att hålla duktus öppen. Det kan man göra genom att tillsätta ett hormon via dropp. Om duktus är öppen så kan syrefattig blod blandas med syrerikt och uppnå tillräckligt hög syresättning för att han ska kunna klara sig. Paradoxalt nog så är hålet i skiljeväggen positiv då blodet kan blandas även där. Så svaret på fråga ett är ja, han kommer kunna klara sig efter födseln tillräcklig länge för att en operation ska kunna genomföras. 
På andra ställen i bloggen förklarar Christer i långa stycken helt utan personliga kommentarer. Här är dock även förklaringen delvis färgad av det aktuella fallet. Samtidigt som han beskriver hur det fungerar generellt beskriver han också hur det fungerar för just Ludvig.

Bloggarens kunskapspositioneringar är beroende av den egna, personliga erfarenheten. I en studie av bloggares skribentidentiteter (efter Ivanič, 1998) undersöks hur olika identiteter ger olika möjligheter till kunskapsbyggande (Bellander, Karlsson \& Nikolaidou 2018). Det blir tydligt att identiteten som kompetent och ansvarstagande förälder möjliggör lärande på ett annat sätt än identiteten som anatomiskt kunnig expert på en viss typ av hjärtfel. Båda identiteterna kan intas genom bloggandet, ibland i samma inlägg, men den senare innefattar vanligen en uttalad ambition att förklara för andra och därmed inta en lärarroll. Denna lärarroll motiveras av bloggarna med att de själva hade velat hitta lättförståelig men korrekt information om just sitt barns hjärtfel, och om vad det innebär för barnet i vardagen. Genom att skriva om detta för andra, och därmed göra råd och annan kunskap från experterna mer relevant, formulerar bloggarna också för sig själva den kunskap de byggt.

Flera informanter berättar i projektets intervjuer att de fătt rådet att inte själva läsa bloggar, något som bekräftas av att detta flera gånger sägs under konsultationssamtalen. Bloggar ses alltså av vårdpersonalen som en icketillförlitlig kunskapskälla, framför allt eftersom de sannolikt oftast handlar om barn med andra typer av hjärtfel än det aktuella (Bellander \& Nikolaidou 2017). Kunskapens kvalitet bedöms alltså utifrån hur medicinskt och anatomiskt relevant den är. Därtill handlar bloggen om ett enskilt barn, och det som gäller för det barnet är inte nödvändigtvis giltigt för ett annat barn med samma hjärtfel. Bloggens berättelse ger alltså anekdotisk kunskap snarare än vetande som baseras på medicinvetenskapens evidens eller erfarenhet. Sett ur föräldrarnas perspektiv kan dock bloggen sägas ge den relevans som konsultationssamtalet inte förmår, nämligen kunskap om 
hjärtfelets effekter insatt i ett vardagligt sammanhang. När säker kunskap om det aktuella barnets framtid saknas kan andras erfarenheter av liknande tillstånd fylla en lucka.

Sammanfattningsvis vänder bloggen på den asymmetri som etablerades i konsultationssamtalen, där (de blivande) föräldrarna är mottagare av information och har en svag kunskapsposition. I bloggen bygger skribenten på just sin personliga erfarenhet som förälder, och kan utifrån den växelvis vara just personlig eller rent undervisande. Dialogen med eventuella läsare är här nedtonad, och de få kommentarer som bloggarna får är allmänt stöttande och bidrar sällan med ny information, till skillnad från forumdiskussionerna. Precis som i forumen är meningsskapandet i bloggarna starkt intertextuellt, särskilt i de delar som handlar om de medicinska aspekterna. Bilder lånas och modifieras, och textbitar kopieras. När bloggarna refererar explicit till medicinska texter kan det tolkas på olika sätt: dels som ett sätt att stärka sin egen kunskapsposition i förhållande till läsarna, dels som en service till den som vill läsa vidare. Det senare kräver en hög grad av inlevelseförmåga och identifikation med läsaren, och ett reflekterande förhållningssätt till den egna rollen som bloggare.

\section{Hälsokommunikation som sakprosafält?}

Genomgången av de tre fall vi valt ut från projektets material ger en bild av hur dynamiken mellan medieringsformer, kunskapspositioner och framställningssätt kan se ut i en reell kunskapsbyggande process. Att Internet fört med sig kommunikationsformer som bryter upp den prototypiska dikotomin mellan tal och skrift är vid det här laget väl känt. Utifrån våra analyser av forum och bloggar kan vi dock gå ett steg längre än att säga att skriften används på otraditionella och mer dialogiska sätt. Snarare handlar det om att Internet skapar olika typer av gemenskaper som i sin tur utnyttjar de medierande resurserna för att bygga sin interaktion (Bellander \&
A. Karlsson og M. Landqvist
$24 / 31$
Sakprosa.no 
Landqvist. inskick.). Centralt i båda fallen är öppenheten och möjligheten för personer som inte känner varandra att kommunicera, förmedla kunskap och successivt bygga expertis utifrån en plattform av personlig erfarenhet. Vårt exempel på talad kommunikation, konsultationssamtalen, är däremot en sluten och tydligt reglerad verksamhetstyp, som resulterar i en i huvudsak monologisk framställning. Även om läkaren och de gravida sitter nära varandra i ett litet konsultationsrum blir interaktionen, av olika skäl, aldrig intensiv. Situationens tyngd och betydelse gör att läkarens expertis måste få stort utrymme. Dessutom ska flera olika ämnen behandlas under den begränsade tid som samtalet varar. Därför har de som lyssnar begränsade möjligheter att ge substantiell återkoppling eller reflekterande kommentarer.

I de andra fallen utmanas dikotomin mellan expert och lekman på flera sätt. I samtliga sammanhang är kunskap ett viktigt kapital, men man skulle kunna säga att olika typer av kunskap (och grund för kunskap) tillskrivs olika värde i de olika kontexterna. Det är inte nödvändigtvis så att den professionella representanten, här läkaren, alltid har den största auktoriteten. Den potentiellt relevanta medicinska kunskapen om det område som det här är frågan om, medfödd hjärtsjukdom, är större än vad en enskild läkare kan omfatta, och än mer informera om under det i sammanhanget korta konsultationssamtalet. För ytterligare kunskap är det vanligt att läkare hänvisar till utvalda medicinska sidor, ofta på engelska, med information som kan bedömas som tillförlitlig.

Men det finns också relevant kunskap som den professionella närmast per definition inte omfattar, eller inte har möjlighet att förmedla. Det kan handla om sådant som moraliska eller andliga perspektiv, anekdotiska exempel på hur det gått i olika fall eller om hur livet med ett hjärtsjukt barn kommer att fungera för den aktuella familjen. Här blir så kallade lekmannaexperter viktiga, dvs. personer med egna erfarenheter av det liv som ligger framför paret. Internet har här inneburit stora förändringar när det gäller att få
A. Karlsson og M. Landqvist 
tillgång till andra personers erfarenhet. Nätet kan i själva verket sägas ha bidragit till att lekmannaexpertis kunnat utvecklas och därtill få hög värdering i många sammanhang (om än inte alltid av vården). Att delta i forumdiskussioner om medicinska tillstånd medför många gånger en lättnad för nya, oerfarna deltagare, och så småningom kan de själva ge andra stöd och agera lekmannaexperter.

Den gräns som trots allt framstår som stark är den kring vårdgivaren som institution och det ansvar som hör till den. Institutionella roller regleras av legitimationer, lagar och andra regleringar. Till skillnad från roller som har med kunskap och expertis att göra, eller med identiteter som producent eller konsument av kunskapsförmedlande text, ligger den institutionella rollfördelningen fast, opåverkad av de glidningar som bland annat Internet möjliggör. I själva verket är det i glappet mellan institution och ickeinstitution som de luckor och behov uppstår, som bloggar och lekmannaexperter fyller i det moderna kommunikationssamhället. Den institutionella rollen ställer krav på evidens och avgränsning av professionellt ansvar. I det aktuella fallet har läkarna och sjuksköterskorna att förhålla sig till abortlagstiftningen, som på många sätt påverkar den roll de kan inta. De kan inte gå in i en behandlande och vårdande roll förrän de faktiskt har en patient, och de får inte påverka den gravida att fatta ett visst beslut. Detta begränsar deras expertroll i denna specifika situation, och öppnar samtidigt dörren för andra experter, som saknar dessa restriktioner.

Hur kan då studier av patienters kommunikativa processer efter en hjärtfelsdiagnos bidra till en utveckling av begreppet sakprosa? Kvalificerar sig projektets material alls som sakprosa, ens i vidare mening? Konsultationssamtalen är de som ligger närmast det som brukar kallas professionell kommunikation. Här informerar en fackkunnig expert en ickefackkunnig lekman, med ett framställningssätt som är starkt monologiskt men som är muntligt. Medicinska facktexter skulle vara för svårtillgängliga för
A. Karlsson og M. Landqvist
$26 / 31$
Sakprosa.no 
paren, och informationstexterna på webbplatser som Vårdguiden 1177 är inte tillräckligt detaljerade och anpassade till det aktuella fallet. Den professionella kommunikationens krav på såväl evidensbasering som relevans för det aktuella fallet gör förmedling genom skriven, rentav tryckt text, svår. Det mest effektiva är att förmedla det hela muntligt och multimodalt, med stöd av en skiss som dessutom försetts med de centrala facktermerna.

Forumdiskussionerna och bloggarna är båda exempel på hur ickeprofessionella skapar mening genom skrift, om ett komplicerat fackområde. Här måste konstateras att forumdiskussionerna i högre grad än bloggarna uppfyller Berges (2001) krav på att vara inriktad på "sak" och inget annat. Dock är formen här utpräglat dialogisk. Bloggarna har inslag av saklig, monologisk text, men makrogenren är en personlig narrativ om livet och vardagen. Lekmannaproducerad sakprosa förefaller alltså här integreras i socialt syftande genrer och interaktionsformer, utan att därför bli mindre saklig och funktionell. Liknande iakttagelser gör Kløve Juuhl (2013) i sin studie av ungdomars digitala texter. Hon drar sig heller inte för att skifta perspektiv och tala om "det mykje skrivne" som en grund för att inkludera denna typ av texter i sakprosakategorin.

Om inget av detta skulle räknas som sakprosa skulle enligt vår mening sakprosa bli ett mycket snävt begrepp som inte bidrar tillräckligt till vår förståelse av texter som resurs för faktabaserat kunskapsbyggande i offentligheten. Om samtliga dessa exempel snarare inkluderas blir det istället tydligt att prototypdefinitionen bör problematiseras. Kanske bör man i så fall även fundera över vad det är sakprosa egentligen făngar, som inte begrepp som interaktion eller meningsskapande gör.

Expertroller förhandlas i varje situation. Gränserna för vad som är fackkunskap är långt ifrån skarpa, och det är inte självklart vem som ska avgöra vems texter som har värde (som litteratur eller kulturtext) eller vilken skribentroll som ska räknas som författarroll. Utmaningen för en modern
A. Karlsson og M. Landqvist
$27 / 31$
Sakprosa.no 
fackkommunikationsforskning, även den som säger sig fokusera sakprosa, borde därför vara att försöka förstå dynamiken och nätverken som är involverade när saklig kunskap görs relevant för verkliga livssituationer. Även för utbildningen av professionell kommunikationskompetens, i tal och skrift, är en medvetenhet om det gränsöverskridande meningsskapandet avgörande, inte minst för att förstå var gränserna för den egna professionens ansvar och räckvidd faktiskt går.

\section{Litteratur}

Bellander, T. (2016). Bloggens roll för hälsolitteracitet och kunskapsbyggande i informationssamhället - En genreanalys av strukturella och språkliga mönster i bloggar om barn med hjärtfelsdiagnos. I: RASK Internationalt tidsskrift for sprog og kommunikation 43. Syddansk universitet.

Bellander, T. \& Nikolaidou, Z. (2017). Building health knowledge online. Parents' online searches on congenital heart defects. I: Literacy \& Numeracy Studies 25:1 https://doi.org/10.5130/lns.v25i1.53.58

Bellander, T., Karlsson, A. \& Nikolaidou, Z. (2018). Blogging as a Health Literacy Practice. Identity construction and knowledge-building in the writing of parents of children with heart defect. I: Halllsten, Stina \& Nikolaidiu, Zoe (red.): Explorations in Ethnography, Language and Communication: Capturing Linguistic and Cultural Diversities. Text- och samtalsstudier från Södertörns högskola 7. Huddinge: Södertörns högskola. S. 127-152.

Bellander, T. \& Landqvist, M. (inskickad): Becoming the expert. Constructing health knowledge and buidling epistemic communities online. 
Berge, K. L. (1993). Hva er det som kvalifiserer et budskap som “tekst”? Tekst og kontekst kultursemiotisk vinklet. I: Fretheim, Thorstein m.fl. (red.): Tekst $i$ kontekst. Oslo: Novus.

Berge, K. L. (2001). Det vitenskaplige studiet av sakprosa. I: Berge, Kjell Lars, Breivega, Kjersti Rongen, Roksvold, Thore Roksvold og Tønnesson, Johan L. (red.): Fïre blikk på sakprosaen. Sakprosa nr 1. Oslo.

Berge, K. L. \& Tønnesson, J. (2009). Forskningen om sakens prosa. I: Sakprosa 1:1.

Englund, B., Ledin, P. \& Svensson, J. (2003). Vad är sakprosa? I: Englund, Boel \& Ledin, Per (red.): Teoretiska perspektiv på sakprosa. Lund:

Studentlitteratur.

Karlsson, A. \& Makkonen-Craig, H. (red.) (2014). Analysing text AND talk: Att analysera texter OCH samtal. Uppsala: Arbetsrapporter om modern svenska. FUMS Rapport nr 233.

Karlsson, A. \& Strand, H. (2012). Text i verksamhet: mot en samlad förståelse. I: Språk \& stil 22:1, tema: Text. S. 110-134.

Kløve Juuhl, G. (2013). I det mykje skrivne. En undersøking omungdoms digitale tekstar i skule og fritid som situerte, retoriske handlingar. Oslo: Oslo Universitet.

Landqvist, M. (2016). Sense and sensibility - online forums as epistemic arenas. I: Discourse, Context \& Media 13(B). S. 98-105.

Landqvist, Mats. (inskickad): Layman expertise in medical online forums. Social legitimation and semantic realization in a discussion thread.
A. Karlsson og M. Landqvist
$29 / 31$
Sakprosa.no 
Landqvist, M. \& Karlsson, A. (u.u.): ”Dom tar emot det, tar tag i det och sen så går man vidare”. Semantiskt arbete för gemensamt kunskapsbyggande i konsultationer om medfödda hjärtfel hos foster. Antagen för publicering i Språk och interaktion.

Ledin, P. (1999). Texter och textslag - en teoretisk diskussion. Rapport från projektet Svensk Sakprosa. Lund.

Linell, P. (2009). Rethinking language, mind, and world dialogically: interactional and contextual theories of human sense-making. Charlotte, NC: Information Age Publ.

Rose, D. \& Martin, J. R. (2012). Learning to write, reading to learn: genre, knowledge and pedagogy in the Sydney school. Sheffield, United Kingdom: Equinox Publishing.

Maton, K., Hood, S. \& Shay, S. (2015). Knowledge-building: Educational studies in Legitimation Code Theory. Routledge.

Melander Marttala, U. \& Mattsson, E. (2017). Fackord i samtal och texter om barns hjärtfel. I: Svenskans beskrivning 35. S. 215-227.

Ivanič, R. (1998). Writing and identity: The discoursal construction of identity in academic writing. Amsterdam; Philadelphia, Pa; John Benjamins. https://doi.org/10.1075/swll.5

Greenhalgh, T. (2014). Evidence-based medicine: A movement in crises? I: BMJ 348: g3725. https://doi.org/10.1136/bmj.g3725 
Giles, D., Stommel, W., Paulus, T.; Lester, J. \& Reede, D. (2015).

Microanalysis of online data: The methodological development of "digital CA".

I: Discourse, Context \& Media 7 (2015): 45-51.

https://doi.org/10.1016/j.dcm.2014.12.002

Sackett, D. L., Rosenberg, W. M. C, Gray, M. J. A, Haynes, B. R. \&

Richardson, S. W. (1996). Evidence based medicine: What it is and what it

isn’t. I: $B M J$ 312(7023): 71-72. https://doi.org/10.1136/bmj.312.7023.71

Sarangi, S. (2000). Activity types, discourse types and interactional hybridity: the case of genetic counselling. Discourse and social life: 1-27.

Svensson, J. \& Karlsson, A. (2012). Inledning: Text, textforskning och textteori. I: Språk \& stil 22:1, tema: Text. S. 5-30.

Tønnesson, J. (2001). Vitenskapens stemmer. Sakprosa nr 2. Oslo.

Tønnesson, J. (2008, 2012). Hva er sakprosa. Oslo: Universitetsforlaget. 